UDC 159.9.019.43

DOI: $10.52534 / \mathrm{msu}-\mathrm{pp} .7(3) .2021 .110-117$

Olena F. Yatsyna*

Uzhhorod National University

88000, 3 Narodna Sq., Uzhhorod, Ukraine

\title{
Mobbing Syndrome as a Personality Disorder: The Consequences of Complicated Socialisation in the Symptoms of Occupational Destruction
}

\author{
Article's History: \\ Received: 22.05.2021 \\ Revised: 27.06 .2021 \\ Accepted: 20.08.2021
}

\section{Suggested Citation:}

Yatsyna, O.F. (2021). Mobbing syndrome as a personality disorder: The consequences of complicated socialisation in the symptoms of occupational destruction. Scientific Bulletin of Mukachevo State University. Series "Pedagogy and Psychology", 7(3), 110-117.

\begin{abstract}
The relevance of this study is conditioned by the need to identify the key preconditions and causes of increased violence in the workplace to find new methods of combating mobbing at both international and national levels. The purpose of this study is to analyse mobbing as a psychosocial and medical phenomenon, which is logical to consider with the symptoms of professional destruction. The study of mobbing syndrome took place in two stages based on synergetic methodology using such general scientific research methods as analysis, synthesis, comparison, and systematisation. The study identified the specific features of mobbing at the Ukrainian and world level. The authors considered the main causes of mobbing behaviour as a social issue, as a social phenomenon of the organisation, and as a form of collective violence. The study provides reasoning regarding the necessity of studying the mobbing syndrome from the standpoint of psychosocial and medical aspects. The authors analysed fractal dynamics of mobbing formation, presented in somatogenesis, psychogenesis, and sociogenesis. The study presents the main predictors of professional destruction, which include individual-personal, i.e., total control, manipulation, and conflict, etc., and clinical, which include emotional instability, narcissism, steroidism, and more. It is determined that the types of individual's socialisation develop in accordance with the defensive mechanisms that prevail upon restoring one's security. The study considered the specific features of the clinical aspect of personality disorder. The authors provided a general description of the narcissistic type of personality disorder as a structure of mobster. The practical value of this study lies in the interdisciplinary investigation of mobbing syndrome based on psychosocial and methodological factors
\end{abstract}

Keywords: psychological predictor, bullying, stress, group dynamics, destructive interaction

\section{INTRODUCTION}

At present, the issue of employment transcends the exclusively economic space. The relationship between an employer and an employee is established on the principle of "supply and demand", but in the context of a certain psychological environment, which implies compliance with personal boundaries. Violation of employees' boundaries stimulates mobbing in the team. As statistics show, mobbing in the modern labour sphere is not uncommon. According to a survey conducted in 2020 by the British company SME Loans, among 2,000 employees, $23 \%$ were bullied in the workplace, $25 \%$ of respondents feel violated at work, and $12 \%$ of respondents struggle to find friends at work [1]. From the standpoint of age gradation, according to the results of the study, employees aged 18 to 24 years are most frequently victims of psychological pressure at work [1]. The percentage of mobbing changes in proportion to the age of employees [1]. Statistics from the American Workplace Bullying Institute for 2021 show that $30 \%$ of all American adults experienced office bullying, which is 76.3 million employees [2].

This increase in the number of mobbing victims necessitates new research aimed at studying the prerequisites, causes, and consequences of mobbing as a form of psychological pressure. Among the researchers who have studied mobbing within the framework of Ukrainian science, it is advisable to mention L.V. Shchetinina, S.G. Rudakova, 
K.O. Drobynska [3], O.T. Smuk [4], and V.V. Honcharuk [5]. L.V. Shchetinina, S.G. Rudakova, and K.O. Drobynska considered the experience of combating mobbing on the example of Norway, Germany, Belgium, and Italy [3]. The authors believe that only proper regulation of countering psychological pressure at work can reduce the percentage of mobbing victims [3]. According to O.T. Smuk, mobbing is a global and massive consequence of malignant aggression caused by psychological and ethical factors [4]. V.V. Honcharuk considers mobbing "a form of discrimination that is used as a psychological terror on the part of the entire team or its member in relation to an individual employee" [5].

In the context of the global spread of mobbing, it is worth paying attention to the results of foreign research. Thus, D. Maran, S. Bernardeli, and A. Varetto, based on numerous court decisions, considered the types, motives, and consequences of mobbing [6]. The authors discovered that, for the most part, mobbing occurs in private companies, the victims of which are women under the age of 45 [6]. Features of mobbing in each individual case depend on the psychological types of the victim and mobber [6]. Researchers B. Erdemir, S. Demir, and Yu. Osal considered mobbing from the standpoint of academic leadership [7]. The authors are certain that mobbing behaviour is much less common in companies with positive management [7]. Ch. Prevost and Ye. Khant analysed cases of mobbing in the professional team of the university [8]. According to scientists, mobbing is associated with gender, sexual orientation, ethnicity, and race, etc. [8].

Taking into account the above, mobbing is considered from the standpoint of various aspects, however, mobbing as a consequence of complicated socialisation in the symptoms of professional destructions is understudied. Therefore, the purpose of the article is an analytical review of mobbing as a psychosocial and medical issue, which is logical to consider in relation to the symptoms of professional destructions.

As an interdisciplinary issue, this research subject is insufficiently covered and requires in-depth study in the future. Considering the fact that it is not possible to cover all the stated tasks within the framework of an article, the authors pay attention to certain provisions and scientific reflection of published studies for further research on the psychological operationalisation and verification of mobbing.

\section{LITERATURE REVIEW}

Analysis of the latest research of foreign and Ukrainian specialists on the manifestations and consequences of mobbing as a form of psychological violence in the workplace allows them to be grouped according to the subject of research: the history of emergence, features and key characteristics, psychological types of victims and mobbers, the main stages of mobbing behaviour, etc. Thus, for example, H. Leshchuk analyses mobbing as a social issue, the external causes of which are shaped at the level of society or group in the context of the life cycle, morality, principles, and laws of functioning of an individual collective [9]. Among the external causes of mobbing, the author identifies a status hierarchy, herd instinct, primitive communicative reactions, age-related individual development characteristics, and a low cultural and ethical level [9]. Internal reasons are laid down at the level of each individual, so they provide for taking into account individual experience, views, psychological state, and so on. According to H. Leshchuk, the prerequisites for mobbing are based precisely on internal factors, since external ones only stimulate the process [9]. However, the researcher mistakenly claims that these causes do not depend on individual personality traits, which contradicts the principles of the philosophical and psychological level (the principle of consistency, determinism, unity of the psyche and activity).

The causes of mobbing are also investigated by N. Larchenko [10]. The author focuses on the following: mobber's desire for retribution, personal anger, envy, boredom, family issues, mobber's self-confidence and desire to assert themselves with the help of others, positive achievements of the victim (new position or housing, birth of a child), crises in the company, fear, uneven distribution of responsibilities, etc. [10]. These causes determine the focus of mobbing on humiliating the dignity of the employee, underestimating/devaluing professional achievements, success/recognition, which may result in the actual inability/ unwillingness to effectively perform professional functions and/or subordination to the mobber, deprives the desire to show any initiative. In this regard, it should be considered that a person is subjected to psychological trauma due to a stressful situation, it is a condition that, due to the pronounced severity of the reaction, duration, and repeatability, is negatively experienced and can cause certain pathologies.

A separate area of research is mobbing of personnel as a social phenomenon of the organisation. Its causes and consequences are studied by L. Chervinska [11]. The author rightly notes that staff mobbing is becoming more common and explains it by saying that "in modern conditions, due to limited jobs and attractive vacancies, there is increased competition, when a great part of employees are afraid of losing their jobs, and some want to make a career by any means" [11]. The results of a sociological study by Yu. Patlasov and I. Kalmykov in the form of a pilot Internet survey using the Google Form service are of particular interest [12]. 108 people were selected as participants in this survey. On the grounds of the results obtained, $43.9 \%$ of respondents experienced psychological harassment in the workplace. Therewith, $26.2 \%$ stated that they quit their jobs precisely because of mobbing [12]. From the authors' point of view, the hostile relations in the team lead to staff turnover and an increase in the number and duration of sick leave, family vacations, etc. [12]. According to O. Serdiuk and I. Shupt, mobbing in a team occurs for the purpose of psychological pressure and harassment of the most talented and promising employee [13]. The authors consider such situations to be destructive phenomena that notably hinder the innovative development of the enterprise [13].

O. Kachmar considers mobbing as a form of collective 
psychological violence [14]. The researcher is certain that mobbing causes egocentricity and aggressiveness of modern society. However, the elimination of mobbing behaviour occurs only in the case of regular recurrence of negative actions, otherwise - psychological pressure is simply ignored [14]. $K$. Hirniak studied the characteristic features of mobbers [15]. Thus, the author identifies narcissism, the need for the presence of a victim, an "idealistic" self-image, etc. [15].

Notably, Ukrainian researchers actively consider mobbing as a factor in the destruction of occupational health. T.M. Dziuba suggests that as a result of mobbing, "signs of various professional health issues, and, most importantly, the destruction of a sense of the employee's professional existence occur, which directly and indirectly determine the value content of the subjective picture of the individual's life path from the standpoint of its division into life "before and after" the destructive impact" [16]. Therewith, the results of T.M. Dziuba's scientific research allow establishing a correlation using the Pearson rank correlation method between "mobbing" and individual occupational health risk factors [16]. Regarding mobbing that occurs in teaching activities, S. Druzhylov introduces "institutional mobbing", which means "moral persecution of employees using such institutions as personnel certification, qualification exams, consideration of official disputes, etc." [17]. Having studied the features of mobbing in scientific and pedagogical collectives, S. Druzhylov noted that, as a rule, a highly qualified teacher appears as an object of mobbing, showing independence and subjectivity. However, the independence of the subject of labour is manifested in the creative way of performing activities, in the active manifestation of the individual's professional competence. The author argues that an independent person in the team is self-sufficient, but such people have more issues and it is more difficult for them to work successfully and live in the context of environmental expectations. Such a specialist is the first to be mobbed, the first to be fired as an inconvenient, undesirable employee. Such people have their flaws, but unlike the "adapters", they are constantly evolving and self-improving, they are extraordinary, different from the "mediocre" majority [17].

Researchers I. Bukhtiiarov ta M. Rubtsov analysed cases in which aspects of general and clinical pathology are described by means of diagnostics of mobbing victims suffering from psychological/psychosomatic diseases [18]. It was discovered that mobbing and bullying as stressful factors can cause poor performance and lead to serious health and mental disorders of employees, the symptoms of which are similar to post-traumatic stress disorder (PTSD). In extreme cases, mobbing and bullying can cause serious illnesses, professional unfitness, and early disability, social isolation, and even suicide. It was found that even in a relatively short period of mobbing, PTSD is diagnosed. Later (about a year or two), a general neurosis (anxiety) may develop. In the future, severe depressive and/or obsessive syndromes may regularly occur. At this stage, the sufferer's personality undergoes profound and irreversible changes [18]. According to the results of special studies, psychological terrorism leads the "target/victim" of mobbing to stress. Therefore, the key psychological predictor of mobbing should be considered stress in the workplace. In this context, there is a linear relationship between stress as a non-specific (consisting in adaptation) response of the body to any action which overloads the adaptive capabilities of a person and causes diseases of the body: the musculoskeletal system, cardiovascular, and digestive systems. At the level of the psyche, there is an unwillingness to go to work, decreased performance, nervous breakdowns, depression, and so on.

Therefore, the analytical review of mobbing as a psychosocial and medical issue conducted based on the analysis of Ukrainian and foreign publications allows considering the phenomenon under study as a system: mobbing - a professional environment in which there are dysfunctional factors that lead to professional destruction and personality disorder.

\section{METHODOLOGY}

The outlined tasks of theoretical research are implemented within the framework of the post-non-classical paradigm using a synergistic methodology. As a methodological basis for research, synergetics allows describing and interpreting the results of research on "mobbing" in social reality at an interdisciplinary level, substantiate the need for a systemic psychosocial and medical approach in the study of mobbing syndrome as a personality disorder, and identify the symptoms of professional destructions. Thus, the synergistic methodology creates a unified field of interdisciplinary communication.

The transfer of obtained data to dialogues of various disciplines: social psychology, personality psychology, clinical psychology, medicine, sociology, pedagogy contributes to interdisciplinary knowledge exchanges and orient researchers in the course of cognitive activity to identify general patterns, mechanisms of the establishment of the studied phenomenon, and its impact on the individual. The chosen method outlines new aspects of studying and evaluating the relationship of personality traits of mobbing "target/victim", the actual personal causes of mobbing, the symptoms of professional destructions in the mobbing - a professional environment, and presents a synergistic model of mobbing, covering a multidisciplinary and integral approach to the issue of psychological violence/terrorism.

Furthermore, in the context of synergetic methodology, the author used such general research methods as analysis, synthesis, comparison, and systematisation. The analysis made it possible to study the scientific developments of Ukrainian and foreign authors on the definition and characteristics of mobbing syndrome. The synthesis method was applied to examine the individual components of destructive professionogenesis and the development of mobbing, respectively, in integrity and unity. To organise the components of psychosomatosocial disorders, reproduce the fractal dynamics of mobbing development, consider 
professional destructions in the context of mobbing syndrome and personality types based on the dominant defensive reaction, the systematisation method was used. The comparison allowed correlating different approaches to the analysis of mobbing in the context of psychological science research.

Based on this methodology, the study of mobbing syndrome as a personality disorder was conducted in two stages. The first stage provided for the examination of the theoretical basis of research in the form of scientific and methodological literature on the selected issues of Ukrainian and foreign specialists. During the first stage, it was discovered that mobbing syndrome should be divided into separate components, which become the subject of research around the world. The second stage of the study is aimed at identifying and analysing specific components of mobbing syndrome in accordance with the chosen subject, namely the symptoms of professional destructions. In the course of the second stage, the dynamics of mobbing development in conditions of psychosomatosocial disorders were described and the features of complicated socialisation of agents were considered.

\section{RESULTS AND DISCUSSION}

\section{Mobbing syndrome as a personality disorder: Symptoms of professional destructions}

Upon studying mobbing, researchers P. Sidorov, I. Novikova, in "Mental medicine: methodology and practice", concluded that it is one of the syndromes of destructive professionogenesis [19]. The authors cover the destructive professionogenesis, that is, psychosomatosocial disorders caused by the negative impact of work. Based on the provisions, researchers distinguish the following components (Fig. 1) [19].

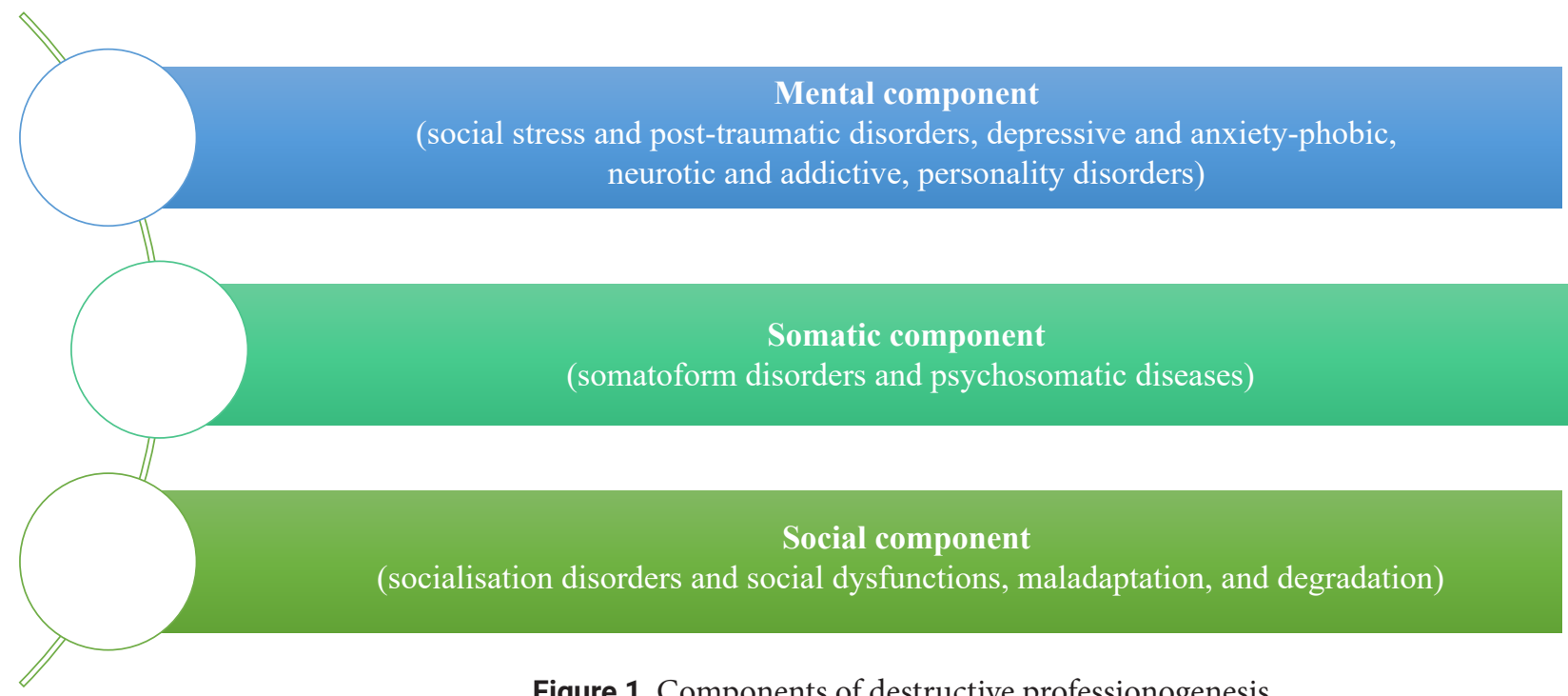

Figure 1. Components of destructive professionogenesis

According to the authors, mobbing as a destructive professionogenesis characterises the area of obtaining a harmful result from the standpoint of society, since, when people are focused on destructive professional values and results, they set socially unacceptable goals and use means that are destructive for the team. Therewith, the study considers the fractal dynamics of mobbing development compiled by the authors, which is a considerable contribution to the study, presented in three vectors (Table 1) [20].

Table 1. Fractal dynamics of mobbing development

\begin{tabular}{|c|c|c|c|c|c|c|}
\hline $\begin{array}{l}\text { Ontogenesis } \\
\text { vectors }\end{array}$ & $\begin{array}{l}\text { Precondition } \\
\text { fractal: familial } \\
\text { dysontogenesis }\end{array}$ & $\begin{array}{l}\text { Latent: } \\
\text { diathesis }\end{array}$ & $\begin{array}{l}\text { Initial: } \\
\text { functional } \\
\text { disorders }\end{array}$ & $\begin{array}{l}\text { Detailed } \\
\text { clinical } \\
\text { picture }\end{array}$ & $\begin{array}{l}\text { Chronisation: } \\
\text { forms and } \\
\text { types of the } \\
\text { progression }\end{array}$ & Result \\
\hline Somatogenesis & $\begin{array}{l}\text { Hereditary } \\
\text { burden }\end{array}$ & $\begin{array}{l}\text { Violation } \\
\text { of neuro } \\
\text { processes }\end{array}$ & $\begin{array}{l}\text { Somatoform } \\
\text { dysfunctions }\end{array}$ & $\begin{array}{l}\text { Somatised } \\
\text { disorder }\end{array}$ & $\begin{array}{c}\text { Psychosomatic } \\
\text { illness }\end{array}$ & $\begin{array}{l}\text { Somatoneurological } \\
\text { complications }\end{array}$ \\
\hline Psychogenesis & $\begin{array}{l}\text { Neurosogenic } \\
\text { family }\end{array}$ & $\begin{array}{l}\text { Accentuations } \\
\text { of personality }\end{array}$ & $\begin{array}{l}\text { Psychopathisation } \\
\text { of the individual }\end{array}$ & $\begin{array}{l}\text { Personality } \\
\text { disorder }\end{array}$ & $\begin{array}{c}\text { Neurotic } \\
\text { (paranoid) } \\
\text { development }\end{array}$ & Mental defect \\
\hline Sociogenesis & $\begin{array}{l}\text { Disharmony of } \\
\text { family relations }\end{array}$ & $\begin{array}{l}\text { Socialisation } \\
\text { disorders }\end{array}$ & $\begin{array}{l}\text { Reduced } \\
\text { frustration } \\
\text { tolerance }\end{array}$ & $\begin{array}{l}\text { Professional } \\
\text { deformity }\end{array}$ & $\begin{array}{c}\text { Social } \\
\text { decompensation } \\
\text { and isolation }\end{array}$ & $\begin{array}{c}\text { Social } \\
\text { maladaptation }\end{array}$ \\
\hline
\end{tabular}


Considering the vector of psychogenesis, it is conditioned by disorders in the family system. Since people undergo socialisation in the family from the moment of birth, the existing disharmonious relationships between its members become a trigger for psychological self-defence, under the influence of which personality accentuations are shaped and manifest themselves in adolescence. In the future, accentuated traits are involved in the construction of false behavioural patterns, which manifest psychopathisation of the individual with pronounced clinical manifestations indicating a personality disorder with subsequent neuroticism. At the level of sociogenesis, there is a violation of socialisation with subsequent professional deformation, mobbing and, as a result, social maladaptation. Therewith, in the future, even with the reduction/disappearance of adverse socio-psychological factors, a trauma in the family, school or institute, pathocharacterological changes in personality increase. Personality disorders manifest themselves in internal conflicts, interpersonal ones, in particular, in professional activities.

In the context of the research issues, this is illustrated by data on the main personal causes of bossing identified by S. Druzhylov [17]. The researcher describes bossing as:

- "lifestyle", where the managers sacrifice not only valuable employees but also the interests of the organisation or structural division of a particular institution to please their ambitions. Such a boss demonstrates excellence, provokes, manipulates, arranges intrigues, conflicts, confronts the interests of subordinates;

- "compensation of one's own insecurities", which conceals uncertainty, pathological suspicion, and distrust, the desire for self-affirmation at the expense of others;

- "incompetence in the management sphere", which manifests itself in violation of communication with employees, inability to resolve conflicts, conduct professional discussions, total control, the envy of the success of colleagues.

These characteristics indicate a competing position of the mobber/bosser in relation to the employee who is considered an actual or potential rival. Obviously, such a person is destructive, with professional deformities manifested in permissiveness syndrome, violation of rules, professional and ethical standards, and the dominance of a manipulative interaction. Abraham H. Maslow called similar deformations of the personal and semantic sphere metapatology, which "decreases humanity" [21].

Expectedly, professional destruction involves other members who, in a mobbing situation, support the bosser: "like attracts like". As a rule, other employees receive certain preferences from the manager and are included in horizontal mobbing, excusing their biased behaviour by the will to "survive": to preserve the place of work, not to spoil relations with the boss, and so on. In this way, they become a weapon against mobbing's "target/victim" and an ally with the boss. While attempting to create the illusion of their own safety, they discredit their colleague together and in various ways and do not think about the immorality of their actions to please the manager. They are not able to accept the success of their colleagues, they are jealous, and do not develop themselves. Those are the symptoms of a destructive attitude to work and the beginning of de-professionalisation. To define such cases, S. Pakulina uses "professional destruction by the management", which is not capable of reflection and the actions of which cause various somatoprofessional diseases of all participants [22]. In this context, it is also appropriate to mention the overcoming adaptation by S. Pakulina [22], according to which the success of overcoming adaptation is determined not so much by adaptive abilities, but the level of productivity and activity of the individual as a subject of work and life in general. The above can be correlated with the idea of S. Druzhylov on the individual resource of professional development [23]. According to the researcher, there is a transition to a new level of adaptability, which contributes to further personal and professional development. In the opinion of the authors of this study, regardless of mobbing actions, people can maintain their personal integrity if it is distinguished by professionalism. The immorality of mobbing actions indicates the symptoms of professional destruction caused by personality disorder and leads to professional deformity (Fig. 2).

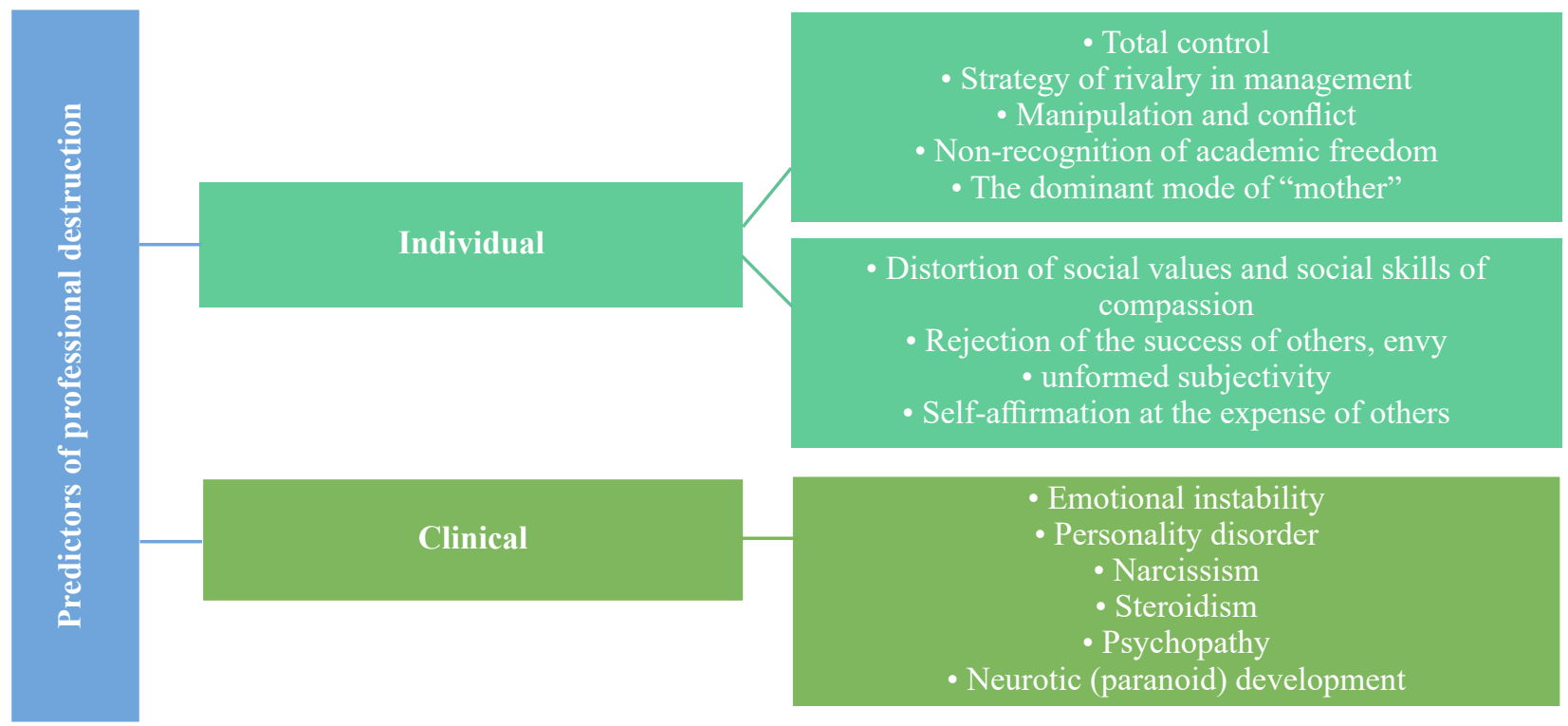

Figure 2. Professional destructions of mobbing syndrome 
Thus, professional destructions are distorted individual-personal and professional qualities, manifested in mobbing syndrome as a negative factor of the professional environment.

\section{Mobbing syndrome as a personality disorder due to complicated socialisation of the agent}

In the context of the above, it is advisable to consider the features of complicated socialisation of agents that stimulate mobbing syndrome as a personality disorder. Numerous studies have been devoted to socialisation as a basic process in sociology and psychology. This process is a determinant of human behaviour, in particular, deviant behaviour. Since socialisation reflects the result of an individual's interaction with the environment, it becomes the subject of new research. Eventually, the social environment is mobile, it is transformed, acquiring new characteristics that also make changes in the internalisation of the individual. In addition to the well-known classical concepts of socialisation (symbolic interactionism, role behaviour, consolidation theory), according to the research subject, it is worth focusing on the theory of J. Arnett [24], in which the author proposes a new classification of socialisation: narrow and broad. Broad socialisation encourages independence, individuality, and self-expression. Its essence is manifested in the fact that the individual is given the opportunity to generate any social practices and choose any path of their own development. Narrow socialisation is aimed at ensuring obedience and consistency, and its actions are aimed at curbing social deviations.
As can be observed, the individual independently chooses the trajectories of his own development. It is important that socialisation type is determined by a certain cultural environment in which it is carried out as assimilation, adaptation, interiorisation, interaction, and transition. Consequently, the individual constructs various personal experiences and learns different patterns of behaviour, respectively, the emphasis will be placed on the mechanisms of this assimilation and the actual content of what is learned. It follows that the activity of the subject is manifested in a selective attitude to the possible role repertoire and in ways of resolving role conflicts; in choosing a particular strategy of behaviour; in ways of self-affirmation and in the attachment/denial of a certain system of values in relation to various spheres of life (family, study, work, recreation).

In this regard, the theory of Karen Horney, devoted to the influence of the environment on personality development, is of particular importance [25]. The individual's motivation, according to the author, is at the heart of anxiety, which leads to the desire for security and the need for self-fulfilment. Any negative experiences are accompanied by a violation of the calm state. Thus, the desire for security is caused by the so-called "basic anxiety" [25]. Attempts to reduce the level of anxiety lead to the development of certain protective mechanisms, as a result of which the following types of protective reactions are established: helplessness, isolation, aggressiveness. In case of excessive use of one of these protective mechanisms by a person, its hypertrophy develops. This dominant defensive reaction later becomes the basis for determining the type of character to which they belong (Fig. 3):

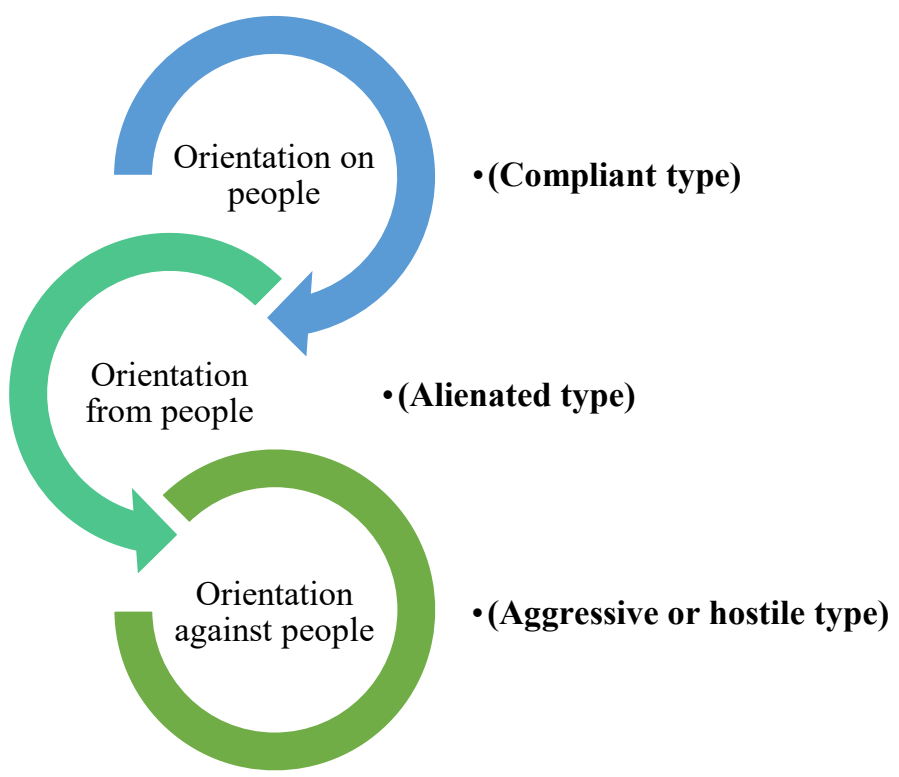

Figure 3. Personality types based on the dominant defensive response

In the context of the studied issues, the orientation against people, which is manifested in a hostile, aggressive, and cruel attitude is considered. The logic of orientation against people is based on the principle "if people are cruel, it is necessary to fight against them or learn how to manage them". Aggressive or hostile individuals are characterised by pragmatism and excessive self-interest without the ability to sympathise, as well as criticism of their environment. They have a huge desire for success, losing becomes a personal disaster. People of the aggressive type are quite moderate and prone to analytics. Moreover, they avoid showing love, compassion, and pity, since they perceive these feelings as a manifestation of weakness and menace. Individuals who are oriented against people live on the principle of power and build activity strategies based on neurotic psychological defenses. Notably, a healthy personality also has all these 
strategies, but a healthy person is able to change them and choose the optimal one in each specific case. Instead, the neurotic person focuses exclusively on one strategy, regardless of the circumstances and necessity [25]. In many cases, neurotic symptoms carry a specific expression of internal moral conflict.

This study considers the above in the clinical aspect. It is well known that personality disorder is characterised by a clear identification of certain traits that, in the future, cause suffering, conflicts, and disability. Nevertheless, deviations from a healthy psyche are directly associated with the level of expressiveness and dominance of a certain trait rather than its presence. The disorder is especially relevant in older childhood and adolescence and continues throughout life. In contrast to neurotic disorders, a personality disorder is accompanied by a lack of criticism and the ability to control one's behaviour.

The above allows proceeding to the characterisation of the personality structure of the mobber. In a particular case, it is worth paying attention to the characteristics of narcissistic personality disorder. Although it is not classified as a separate category in the International classification of diseases, signs of the disorder are inherent in $0.8 \%$ of the total population [26]. According to the American classification of mental illness DSM-IV, people with narcissistic personality disorder are unable to empathise, need recognition of their own greatness on the part of others. The presence of this disease is indicated by high self-esteem, a tendency to fantasise, perception of oneself as a representative of a higher status, the need for worship, a tendency to exploit the environment, envy and arrogance [26]. In this case, the lack of empathy and envy of the achievements of the other, a grandiose sense of self-importance, focusing on one's own uniqueness, superiority, disregard for moral standards, manipulative communication strategy - are inherent in people who have inadequate self-esteem, inauthentic ideas about themselves as a person who meets the criteria of diffuse identity.

To determine individual aspects of a person's character or the extreme limit of exacerbation, pathology, in psychological and clinical classifications, the continuum of emotional, personal, and behavioural phenomena is used.
Therefore, in narcissistic personality disorder, difficulties in social adaptation become permanent, which, as noted above, is expressed by a pattern of stable characteristics: a sense of grandiosity, a need for admiration, and a lack of empathy [27]. Thus, these characteristics can be considered the basis of abnormalities in social adaptation, which is a sign of complicated socialisation of the agent, and if they are considerably expressed, they cause personality disorder. Thus, it can be assumed that dysfunctional interpersonal relationships of mobbers are a marker of personality disorder, in particular, narcissistic personality. The core of the psychological defect of the narcissistic personality, according to Heinz Kohut, is "the inability of the psyche to regulate self-esteem and maintain it at normal level" [27], which is perceived as a symptom of mobbing syndrome.

\section{CONCLUSIONS}

Therefore, in the course of the study, mobbing syndrome was considered as a personality disorder and the consequence of complicated socialisation in the symptoms of professional destruction. The analysis of scientific and methodological literature of Ukrainian and foreign authors allowed confirming globality of mobbing in the modern cultural and professional space, as well as the relevance of considering mobbing in the context of psychosomatosocial disorders. The author substantiated the definition of mobbing as a manifestation of destructive professionogenesis in the context of psychosomatosocial disorders and considered the fractal dynamics of its development, which contributed to the further identification of the characteristic causes of bossing. The paper analysed the influence of the environment on personality development, which is based on the desire for a sense of security. It is noted that focusing on a sense of security and excessive use of the defence mechanisms lead to the development of a certain type of character. The author paid special attention to the aggressive or hostile type and described the key features that contribute to the occurrence of mobbing. The importance and uniqueness of research lie in determining the clinical aspect of mobbing in accordance with the narcissistic personality disorder and highlighting the specific features of its exacerbation.

\section{REFERENCES}

[1] Rosling, L. (2020). 1/4 of UK Employees bullied at work. Retrieved from https://www.smeloans.co.uk/blog/bullyingin-the-workplace-statistics-uk/.

[2] Workplace bulling survey. (2021). Retrieved from https://workplacebullying.org/.

[3] Shchetinina, L.V., Rudakova, S.G., \& Drobynska, K.O. (2018). Mobbing: The essence and the institutional framework for protection of workers. The Problems of Economy, 1(35), 315-320.

[4] Smuk, O.T. (2018). Mobbing as a sequence of malignant aggression. Scientific Bulletin of Uzhhorod University. Series: "Pedagogy. Social Work", 2(43), 260-264.

[5] Honcharuk, V.V. (2020). Counteracting mobbing in labor legal relations. Bulletin of KhNUIA, 3(90), 70-77.

[6] Maran, D., Bernardelli, S., \& Varetto, A. (2018). Mobbing (bullying at work) in Italy: Characteristics of successful court cases. Journal of Injury and Violence Research, 10(1), 17-24.

[7] Erdemir, B., Demir, C., Ocal, J., \& Kondakci, Ya. (2020). Academic mobbing in relation to leadership practices: A new perspective on an old issue. The Educational Forum, 84(2), 126-139.

[8] Prevost, C., \& Hunt, E. (2018). Bullying and mobbing in academe: A literature review. European Scientific Journal, 14(8). Retrieved from https://eujournal.org/index.php/esj/article/view/10620.

[9] Leshchuk, H. (2016). Social aspects of mobbing in professional environment. Scientific Bulletin of Uzhhorod University. Series: "Pedagogy. Social Work", 1(38), 165-167. 
[10] Larchenko, N.A. (2015). Mobbing, or psychological abuse in the work collective. Volgograd: Volgogradskiy oblastnoy tsentr meditsinskoy profilaktiki.

[11] Chervinska, L.P. (2018). Mobbing personnel as a social phenomenon of the organization. Social and Labour Relations: Theory and Practice, 1, 130-136.

[12] Patlasov, O.Yu., \& Kalmyikov, I.S. (2016). Workplace anti-mobbing technologies. The Science of Person: Humanitarian Researches, 1(23), 237-245.

[13] Serdiuk, O.I., \& Shupta, I.M. (2013). Mobbing as a destructive phenomenon in the creative team that inhibits the innovative development of the enterprise. Naukovi Pratsi Poltavskoi Derzhavnoi Ahrarnoi Akademii, 2(1/6), $264-279$.

[14] Kachmar, O.V. (2016). Mobbing as a form of psychological violence in labor collective. Current Problems of Philosophy and Sociology, 14, 58-61.

[15] Hirniak, K.M. (2016). Influence of mobbing on the creation of employees management. Scientific Messenger of LNU of Veterinary Medicine and Biotechnologies. Series: Food Technology, 18(1/4), 167-174.

[16] Dziuba, T.M. (2016). Mobbing as a factor in the destruction of a teacher's professional health. Retrieved from https://kipt.sumdu.edu.ua/pdf/buling/Dzuba_T_Mobbing.pdf.

[17] Druzhilov, S.A. (2011). Psychological terror (mobbing) at a higher education institution department as a form of professional destruction. Psikhologicheskie Issledovaniya, 3(17). Retrieved from https://inlnk.ru/oeRmw.

[18] Bukhtiyarov, I.V., \& Rubtsov, M.Yu. (2014). Mobbing and bullying as occupational stress factors. Safety in Technosphere, 6, 64-74.

[19] Sidorov, P.I., \& Novikova, I.A. (2012). Mental medicine: Methodology and practice. Chișinău: Academic Publishing.

[20] Sidorov, P.I. (2013). Mobbing syndrome: Mental ecology of destructive professiogenesis. Human Ecology, 6, 33-41.

[21] Maslow, A.H. (1999). Motivation and personality. St. Petersburg: Evraziya.

[22] Pakulina, S.A. (2010). Overcoming adaptation in the conditions of mobbing in the teaching staff. Retrieved from http: //www.edit.muh.ru/content/mag/trudy/03_2010/07.pdf.

[23] Druzhilov, S.A. (2006). Individual resources for human professional development. Man and Education, 6, 56-60.

[24] Arnett, J.J. (1995). Broad and narrow socialization: The family in the context of a cultural theory. Journal of Marriage and the Family, 57(3), 617-628.

[25] Horney, K. (1997). The neurotic personality of our time. Moscow: Smysl.

[26] Kokun, O.M., Ahaiev, N.A., Pishko, I.O., \& Lozinska, N.S. (2018). Fundamentals of psychological knowledge about mental disorders for a military psychologist. Kyiv: NDTS HP ZSU.

[27] Kohut, H. (2017). Analysis of the self. A systematic approach to the treatment of narcissistic personality disorders. Moscow: Kogito-Tsentr.

\title{
Олена Федорівна Яцина
}

Ужгородський національний університет 88000, пл. Народна, 3, м. Ужгород, Україна

\section{Синдром мобінгу як розлад особистості: наслідки ускладненої соціалізації в симптоматиці професійних деструкцій}

\begin{abstract}
Анотація. Актуальність дослідження зумовлена потребою у визначенні ключових передумов і причин активізації насильства на робочому місці з метою пошуку нових методів боротьби з мобінгом як на міжнародному, так і державному рівні. Метою роботи є аналіз мобінгу як психосоціального та медичного явища, що логічно розглядати в поєднанні з симптоматикою професійних деструкцій. Дослідження синдрому мобінгу відбувалося у два етапи на основі синергетичної методології з використанням таких загальнонаукових методів дослідження як аналіз, синтез, порівняння та систематизація. У процесі наукової розвідки було виявлено особливості дослідження явища мобінгу на українському та світовому рівні. Розглянуто основні причини мобінгової поведінки як соціальної проблеми, як соціального явища організації та як форми колективного насилля. Обгрунтовано необхідність вивчення синдрому мобінгу з погляду на психосоціальний та медичний аспекти. Проаналізовано фрактальну динамікустановлення мобінгу, представленув соматогенезі, психогенезі та соціогенезі. У дослідженніпредставлено основні предиктори професійних деструкцій, серед яких знаходимо індивідуально-особистісні, тобто тотальний контроль, маніпуляції та конфліктність тощо, та клінічні, до яких належать емоційна нестабільність, нарцисизм, істероїдність тощо. Визначено, що типи характеру соціалізації особистості формуються відповідно до захисних механізмів, що переважають у процесі відновлення стану безпеки. Розглянуто особливості клінічного аспекту розладу особистості. Надано загальну характеристику нарцисичному типу розладу особистості як структури мобера. Практична цінність наукової роботи полягає в міждисциплінарному дослідженні синдрому мобінгу на основі психосоціальних і методичних чинників
\end{abstract}

Ключові слова: психологічний предиктор, психотерор, стрес, групова динаміка, деструктивна взаємодія 